\title{
Energy Quarterly
}

News and analysis on materials solutions to energy challenges www.mrs.org/energy-quarterly | www.materialsforenergy.org

Inside:

EDITORIAL

The Nordic way

\section{ENERGY SECTOR ANALYSIS}

Research on metal hydrides revived for next-generation solutions to renewable energy storage

\section{REGIONAL INITIATIVE}

Deep geothermal ambitions in Norway

\section{ENERGY QUARTERLY ORGANIZERS}

CHAIR Anke Weidenkaff, Empa, Swiss Federal Laboratories for Materials Science, Switzerland and University of Stuttgart, Germany

Anshu Bharadwaj, Center for Study of Science, Technology and Policy, India

David Cahen, Weizmann Institute, Israel

Russell R. Chianelli, University of Texas, El Paso, USA

George Crabtree, Argonne National Laboratory, USA

Sabrina Sartori, University of Oslo and Institute for Energy Technology, Norway

M. Stanley Whittingham, State University of New York at Binghamton, USA

Steve M. Yalisove, University of Michigan, USA

\section{MATERIALS FOR ENERGY BLOG} www.materialsforenergy.org Hosted by the MRS University Chapter of the University of Texas at Austin
Images incorporated to create the energy puzzle concept used under license from Shutterstock.com.

Energy Sector Analysis image: Crescent Dunes Solar Energy Plant in Tonopah, Nev. Image courtesy of SolarReserve.

To suggest ideas for Energy QuARTerly, to get involved, or for information on sponsorship, send email to materialsforenergy@mrs.org.

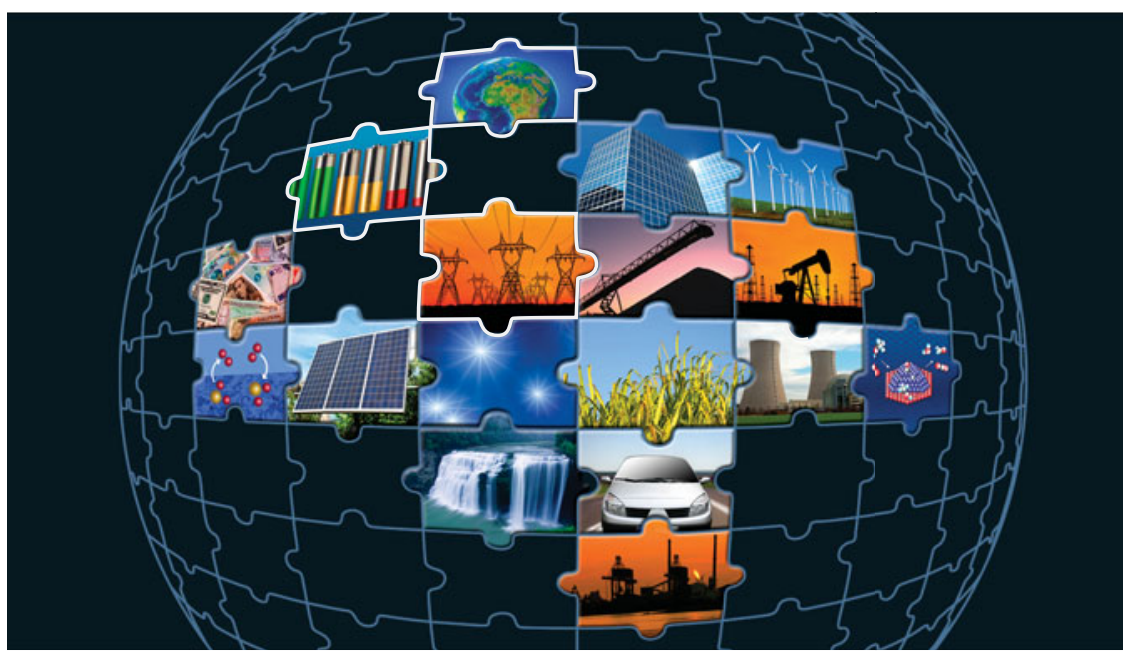

The Nordic way | www.iea.org/media/etp/nordic/NETP.pdf

A global energy system based on low carbon emissions is possible, but very challenging. While the international community has agreed to limit the average temperature increase to $2^{\circ} \mathrm{C}$ by 2050, the five Nordic countries of Denmark, Finland, Iceland, Norway, and Sweden have announced even more ambitious targets toward a carbonneutral scenario, in which $\mathrm{CO}_{2}$ emissions would be reduced by $85 \%$ by 2050 from 1990 levels, with international carbon credits used to offset the remaining $15 \%$.

The Nordic region holds a leading position in renewable energy technologies based on hydroelectric and wind power. However, a study by Nordic research institutions reveals important key challenges to be addressed to reach their further goals.

Energy-intensive industries are at the core of Nordic economies, and to achieve the goal of a $60 \%$ reduction in direct industry emission by 2050 , aggressive policies are necessary for increasing energy efficiency and the use of carbon capture and storage (CCS). Progress in some of these directions has been slow. The halt announced in September by the Norwegian Oil and Energy Minister Ola Borten Moe for a full-scale carbon capture plant at Mongstad shows how current uncertainties over national positions on CCS must be addressed.

Transport represents one-third of the energy-related $\mathrm{CO}_{2}$ emission in the Nordic regions. The goal is to reach $90 \%$ reduced emissions by 2050 . Even though there will be an increasing number of electric vehicles in the years to come, complete electrification of the transport system is unlikely, and other technologies need to be improved and implemented, such as biofuels and hydrogen. Among the existing projects is the so-called hydrogen highway, or HyNor project, where parties from Norwegian industry, government, environmental organizations, and academia joined forces to build an infrastructure of hydrogen stations from Stavanger, in the west coast of Norway, to the Oslo region, some $580 \mathrm{~km}$ driving ride. The project, part of the transnational networking platform, the Scandinavian Hydrogen Highway Partnership, is now in its last phase and is focusing on preparing for the commercial introduction of fuel-cell electric vehicles in the next few years. With their policies, the Nordic countries tell us that a way is possible for a clean energy future.

Sabrina Sartori 